\title{
The Effect of Work Culture and Reward on Military Education Professional Commitments at the Middle of the Center of the Commando for the Development of the Doctrines of Education and Training of the Tni Al (Kodiklatal) Surabaya
}

\author{
R. Anang Dwikuncoro, Makruf Akbar, Suparno Eko Widodo
}

\begin{abstract}
The purpose of this study was to determine the effect of work culture and reward on military education professional commitments at the middle of the center of the commando for the development of the doctrines of education and training of the TNI AL (KODIKLATAL) Surabaya. The research used is a survey with a causal design. The number of respondents was set at 160 educators, the sampling technique was done by simple random sampling from 265 organic educators at the level of Middle Officers who were lecturing in Kobangdikal, Bumi Moro, Surabaya.
\end{abstract}

Index Terms: Commitment, Professional, Reward and Work Culture.

\section{INTRODUCTION}

In this study, the researcher focuses on the influence of work culture and reward on the professional commitment of mid-level military educator staff in command of naval doctrine of education and training (KODIKLATALl) Surabaya Based on this, in a work culture, one's commitment to the organization / company is often an issue very important. So important is some organizations incorporate elements of commitment as one of the requirements to hold a position / position offered in job advertisements. Unfortunately, although this is very common, it is not uncommon for employers and employees to still not understand the meaning of commitment seriously. Though this understanding is very important in order to create conducive working conditions so that the company can run efficiently and effectively.

According to T. Tasmara (2006: 26) the word commitment comes from Latin commitere which is a binding belief (aqad); so firm that it shackles his whole conscience and then moves his behavior toward the direction he believes. Ahmad and Razak (2007) explained that teacher commitment is a

Revised Manuscript Received on September 22, 2019.

R. Anang Dwikuncoro, Universitas Negeri Jakarta, Department of Management (MSDM), Jakarta, DKI Jakarta 13220, Indonesia

Makruf Akbar, Universitas Negeri Jakarta, Department of Management (MSDM), Jakarta, DKI Jakarta 13220, Indonesia

Suparno Eko Widodo, Universitas Negeri Jakarta, Department of Management (MSDM), Jakarta, DKI Jakarta 13220, Indonesia inner strength that comes from within a teacher's heart and outside power about his duties which can have a major influence on the teacher's attitude in the form of responsibility and responsiveness to the development of science and technology. The description implies that the commitment of the teacher (lecturer) professional is an attachment to the tasks and obligations as a teacher (lecturer) that can give birth to responsive and innovative responsibilities and attitudes towards the development of science and technology. In this commitment there are several elements, among others, the ability to understand themselves and their duties, the emanations of the inner attitude (inner strength), external strength and responsiveness to change. These elements give birth to responsibility for the duties and obligations that become a person's commitment so that the task is carried out with full sincerity.

\section{METHODS}

This study uses a quantitative approach, survey methods with path analysis techniques consist of exogenous and endogenous variables. Exogenous variables are work culture and reward, while endogenous variables are professional commitments of military educators. The population in this study were all educators in the Kobangdikal neighborhood, Bumi Moro, Surabaya. The sample in this study is a portion of the population. The sampling technique used is Random Sampling, which is a simple random sampling method. Affordable target populations are organic educators at the level of Middle Officers who are lecturing in Kobangdikal, Bumi Moro, Surabaya. which amounted to 160 people. Calculate the number of samples using the Slovin formula, as follows:

$\mathrm{n}=\underline{\mathrm{N}}$

Description:

$\mathrm{n}=$ Number of Samples

$\mathrm{N}=$ Total Population

$\mathrm{D}=$ Prescribed Precision $^{1}$

Published By:

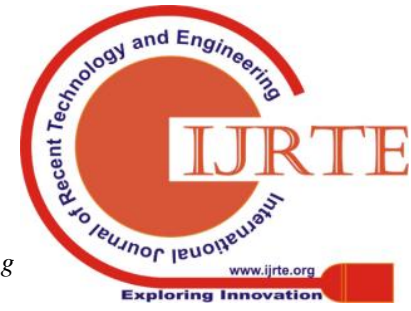


The Effect of Work Culture and Reward on Military Education Professional Commitments at the Middle of the Center of the Commando for the Development of the Doctrines of Education and Training of the Tni Al (Kodiklatal) Surabaya

$\begin{aligned} \mathrm{n} & =\frac{160}{\left(160 \times 0.05 \%{ }^{2}\right)+1} \\ & =\frac{160}{1,00004}\end{aligned}$

$\mathrm{n}=159.994$ or 160 (rounded off)

It is Obtained the sample size $=160$ people, while for the trial of the instrument as many as 30 people. Data collection techniques are carried out using research instruments in the form of questionnaires. The instrument was tested before being used in the study. Testing of these instruments includes validity and reliability testing. From the test results, there are valid and invalid items. An invalid instrument was deleted. The method used in this study is quantitative research with correlational analysis. Correlational research aims to determine the correlation between variables. Correlations between two or more variables are determined using regression equations to make predictions in the population. The total population used in this study was 160 people. The research variables include two variables: $\mathrm{X}_{1}$ variable is Work Culture, $\mathrm{X}_{2}$ variable is Reward and $\mathrm{Y}$ variable is the Professional Commitment of Military Educators, with the following hypothesis:

$\mathbf{H}_{1}$ : Work culture and reward has a significant influence on the professional commitment of military educators.

$\mathbf{H}_{\mathbf{0}}$ : Work culture and reward do not have a significant influence on the professional commitment of military educators.

\section{RESULTS AND DISCUSSION}

The results of this study indicate that the positive direct effect of work culture $\left(\mathrm{X}_{1}\right)$ on the professional commitment of military educators $(\mathrm{Y})$ is 0.291 with a tcount of 5.75 . Indirect influence of work culture $\left(\mathrm{X}_{1}\right)$ on professional commitment of military educators (Y) through Integrity, a large indirect effect of work culture on professional commitment through integrity of: $(0.279)(0.282)=0.079$. So that the influence of the total work culture on professional commitment is 0.369 . The hypothesis tested is:

$\mathrm{H} 0: \beta y 1 \leq 0$

$\mathrm{H} 1: \beta \mathrm{y} 1>0$

The work culture path coefficient value of professional commitment is 0.291 with a $\mathrm{t}_{\text {count }}$ of 5.75 . Because the tcount is greater than the $\mathrm{t}_{\text {table }}$ at $\mathrm{dk}=155$ for $\alpha=0.05$ at $1.98, \mathrm{H}_{0}$ is rejected and $\mathrm{H}_{1}$ is accepted, which means that there is a positive direct effect of work culture variables on the variable of professional commitment which is very significant.

The indirect influence of work culture on professional commitment through integrity is the result of the work culture path coefficient on integrity $\left(\mathrm{p}_{41}\right)$ with the integrity path coefficient on professional commitment $\left(\mathrm{py}_{4}\right)$. The indirect effect of work culture on professional commitment through integrity is: $(0.279)(0.282)=0.079$. So that the influence of the total work culture on professional commitment is 0.369 .

The results of the analysis of the first hypothesis produce findings that work culture has a direct positive effect on professional commitment. Based on these findings it can be concluded that professional commitment is directly influenced positively by work culture. Increasing work culture will lead to increased professional commitment. The results of this study are in line with the opinions of some experts, among them, according to Robbins and Judge (2013: 517):

Culture enhances professional commitment and increases the consistency of employee behavior. From an employee's standpoint, culture is valuable because it spells out things are done and what's important. But we shouldn't ignore the potentially dysfunctional aspects of culture, especially a strong one, on an organization's effectiveness.

Culture increases organizational commitment and increases the consistency of employee behavior. This is clearly beneficial for the organization. Culture is very important because it details the important things to do. The extent to which culture influences organizational effectiveness can be seen by looking at the strength or weakness of the organization's culture. Strong organizational culture will increase organizational effectiveness. Hodson and Sullivan (2013: 58) argue that traditional social scientists distinguish professions from other types of work through the level of expertise and complexity required in the work itself. The assumption is that professional work involves a very complex set of skills, intellectual functions, and knowledge that is not easily obtained and does not belong to just anyone. For this reason, professions are often referred to as knowledge-based occupations.

Julie Prescott and Jan Bogg (2013: 154) below:

Although there has been some support for distinct culture types having an effect on employee attitudes, high solidarity cultures, high sociability cultures, diversity cultures, creativity cultures, and so forth all have different effects on performance and commitment effects that likely vary across different types of organizations and industries.

The theoretical explanation shows that certain types of culture influence employee attitudes, such as a culture of high solidarity, sociability, diversity, and creativity. These types of cultures have different influences on performance and commitment depending on the type of organization and industry.

Meyer, et al. believe that, as well as organizational commitment is best explained by three different component steps; Professional commitment must be explained by three different component steps. They argue that understanding multidimensional professional commitment can have important implications for understanding the psychological bonds between a professional and their particular profession. Adapting their work to organizational commitment, Meyer et al. (2013: 45) defines three different components of professional commitment, they use equivalent terms namely work commitment. This component is called affective 
professional commitment, continuance professional commitment, and normative professional commitment. Boehman (2015: 89), shows that organizational support, overall job satisfaction, and organizational politics are antecedents of affective and normative commitment. Malik et al (2013: 73) in his study showed that job satisfaction, quality of supervision and satisfaction with salary had a significant positive effect on organizational commitment of faculty members.

The direct positive effect of rewards on professional commitment has a reward path coefficient value of professional commitment of 0.288 with a $t_{\text {count }}$ of 5.73 . Because the value of $\mathrm{t}_{\text {count }}$ is greater than the value of $\mathrm{t}_{\text {table }}$ at $\mathrm{dk}=155$ for $\alpha=0.05$ at $1.98, \mathrm{H}_{0}$ is rejected and $\mathrm{H}_{1}$ is accepted, which means that there is a positive direct effect of the variable reward on the variable of professional commitment which is very significant.

The results of the second hypothesis analysis yield findings that rewards have a direct positive effect on professional commitment. Based on these findings it can be concluded that professional commitment is directly influenced positively by reward. Increasing rewards will result in increased professional commitment. The results of this study are in line with the opinions of several experts including S. Samsudin (2013: 48) recruitment is the process of finding, finding, inviting, and establishing a number of people, both from inside and outside the company as prospective workers with certain characteristics as they have stipulated in human resource planning.

Prospective workers who meet the college qualification standards are one who is a professional educator. Jeet and Sayeeduzzafar (2010: 74) in their study showed that human resource management practices such as training, performance appraisal, teamwork and compensation had a significant impact on job satisfaction. Employees. Malik et al (2012: 73) in his study showed that job satisfaction, quality of supervision and satisfaction with salary had a significant positive effect on organizational commitment of faculty members.

The positive direct effect of work culture on reward has a work culture path coefficient value of reward of 0.245 with a $\mathrm{t}_{\text {count }}$ of 3.17. Because the value of the $t_{\text {count }}$ coefficient is greater than the value of $t_{\text {table }}$ at $\mathrm{dk}=158$ for $\alpha=0.05$ at 1.98 , $\mathrm{H}_{0}$ is rejected and $\mathrm{H}_{1}$ is accepted, which means that there is a positive direct effect of the work culture variable on the very significant reward variable.

The results of the tenth hypothesis analysis provide findings that work culture has a direct positive effect on reward. Based on these findings it can be concluded that reward is directly influenced positively by work culture. Increasing work culture will result in increased rewards. The results of this study are in line with the opinions of several experts including Michael Armstrong in Mike Millmore (2007) who said:

Reward as how people are rewarded in accordance with their value to organization. It is concerned with both financial and nonfinancial and embraces the philosophies, strategies, policies, plans and processes used by organization to develop and maintain reward system.

How a person will be given an award that matches the value given to the organization. Rewards can be in the form of financial and non-financial. It focuses on the philosophy, strategy, policy, planning and processes used by the organization to build and maintain a reward system. All of this is done with the aim of maximizing the capabilities or potential of employees or employees in carrying out work or tasks in achieving organizational goals that have been previously determined.

Luthans (2010) said, "it is these more frequent nonfinancial rewards that have a big impact on employee productivity and quality service behaviors". Non-financial benefits have a large impact on employee productivity behavior and service quality. This means that employee productivity is largely determined by the rewards provided by the institution. In other words, institutions or organizations must pay attention to the state of their employees if they want the work culture of each employee to increase as desired. Michael Armstrong (2010) in his book says that:

Reward generally influence performance by providing the means to recognize achievement, competence and merit. Specifically, rewards make an impact on performance by motivating people and by enhancing engagement. Reward can make an impact, (1) reward can make a major contribution to the creation and maintenance of a high performance culture, (2) reward can exert considerable influence over the attraction and retention of talented people as part of a talent management programme.

Rewards generally affect work culture by acknowledging the existence of an achievement, competence and appropriateness. Specifically, rewards make an impact on the work culture by motivating people and by increasing their involvement. Rewards can make a major contribution to the creation and maintenance of a high performance culture, rewards can have a major influence on the attractiveness and retention of talented people as part of a talent management program. Thomas (2012) revealed: As individuals go to work and carry out various tasks, there will be times when they are are invested in the quality of their work and feel responsibility for and commitment to superior job performance.

As individuals, carrying out various work tasks is the time they are invested in the quality of their own work, so they will feel responsibility and commitment to superior work performance.

\section{CONCLUSION}

Based on the results of the calculation of the research data and the results of the data analysis described above, the work culture has a positive direct effect on professional commitment. This means that a good work culture will lead to the commitment of professional middle-level military educators at the Guiding Command of the Indonesian Navy's Education and Training Doctrine (Kodiklatal). Work culture has a positive direct effect on reward. This means

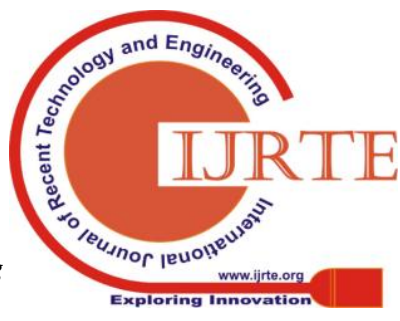


The Effect of Work Culture and Reward on Military Education Professional Commitments at the Middle of the Center of the Commando for the Development of the Doctrines of Education and Training of the Tni Al (Kodiklatal) Surabaya

that a good work culture has resulted in the reward of middle-level military educator staff at the Guiding Command of the Navy's Education and Training Doctrine (Kodiklatal) in Surabaya.

Reward has a positive direct effect on professional commitment. This means that good rewards will lead to the commitment of professional middle-level military educators at the Guiding Command of the Indonesian Navy's Education and Training Doctrine (Kodiklatal). Work culture has a positive direct effect on reward. This means that a good work culture has resulted in the reward of middle-level military educator staff at the Guiding Command of the Navy's Education and Training Doctrine (Kodiklatal) in Surabaya.

Work culture has a positive direct effect on reward. This means that a good work culture has resulted in the reward of middle-level military educator staff at the Guiding Command of the Navy's Education and Training Doctrine (Kodiklatal) in Surabaya.

\section{NOTES}

1. Moorhead, G. dan R.W. Griffin Organizational Behavior. 2nd ed. Boston: Houghton Mifflin Company. 2009.

\section{REFERENCES}

[1] Ilesanmi, O.A. Modern Management. Nigeria: Lagos Fapsony (Nig) Ltd. 2007

[2] Allen, N. J. dan J. P. Meyer. Commitment in The Workplace Theory. Research and Application. Califotnia: Sage Publications, 2017.

[3] Armstrong, Michael Armstrong's Handbook of Reward Management Practice (1518 Walnut Street, Suite 1100, Philadelphia, USA), h. 81

[4] Abbott, A. The System of Professions: An Essay on the Division of Expert Labor. Chicago: University of Chicago Press. 2018.

[5] Britt, Thomas W. James M. Dickinson, Tiffany M. Greene-Shortridge, dan Eric S. McKibben, Positive Organizational Behavior, h. 11

[6] C. A. O'Reilly, dan J. Chatman, "Organizational Commitment and Psychological Attachment: The Effect of Compliance, Identification and Internalization on Prosocial Behavior". Journal of Applied Psychology, $71,2016$.

[7] Greenberg, J. And Robert A. Baron. 2003. Behavior in Organization International Edition, New Jersey: Prentice Hall.

[8] Chien,"M.H.A. Study to Improve Organizational Performance. A View from SHRM". Journal of American Academy of Business, Vol.4,1/2; 2014.

[9] Boehman, Yoseph. Affective, Continuance, and Normative Commitment Among Student Affairs Professionals. A dissertation submitted to the Graduate Faculty of North Carolina State University in partial fulfillment of the requirements for the Degree of Doctor of Education, 2006.

[10] Ismail, Ilham binti dan Yaakob bin Daud. "Influence of Ethical Leadership towards Organizational Commitment in Schools". International Journal of Scientific and Research Publications, Volume 4, Issue 9, September 2014

[11] Collins, R. The Credential Society. New York: Academic Press. 2009.

[12] Hooijberg, Robert., Nancy Lane and Albert Diverse. "Leader Effectiveness and Integrity: Wishful Thinking?", International Journal og Organization Analysis, Vol. 18, No. 1, 2010.

[13] D. McGregor, The Professional Manager. New York: McGraw-Hill, 2017.

[14] Daft, R. L. Organization Theory and Design. 7th ed. Thomson Learning. U.S.A.:South-Western College Publishing, 2010

[15] Lee, T.W., Ashford, S.J., Walsh, J.P. \& Mowday, R.T. Commitmen Propensity, Organizational Commitment and Voluntary Turnover: a Longitudinal Study of Organizational Entry Processees. Journal of Management. Vol. 18, No 1, 2010.

\section{AUTHORS PROFILE}

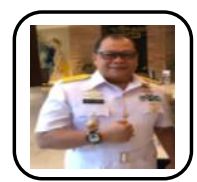

R. Anang Dwikuncoro works in Navy military headquarter in Jakarta .currently studying in universitas Negeri Jakarta concerntrate on Human capital management

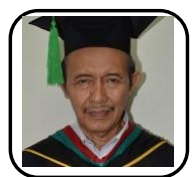

Makruf Akbar works as a senior lecturer in universitas Negeri Jakarta

Who contribute a lot specially on quantitative research.The best position is as for vice director in graduate school in Jakarta State University

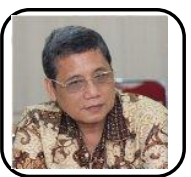

Suparno Eko Widodo works as a senior lecturer in universitas Negeri Jakarta

Who contribute a lot to Human Capital .The best position is as a general director in Ministery of Education 